\title{
EFFECT OF SOME DRUGS AND HERBS ON EXPERIMENTAL RATS SUFFERING FROM OBESITY.
}

\author{
By \\ Farouk, M. El-Tellawy**; Atiat, M. El Bahay*; Abd El- \\ Rahman, M. Attia*; ASHRAF, A. Abd El-Megeid*; \\ and Abd El-Karim, I. Alhussain**. \\ * Nutrition and Food Science Department, Faculty of Home Economics, \\ Helwan University. \\ **Home Economics Department, Faculty of Specific Education, Ain \\ Shams University. Cairo-Egypt.
}

\section{Research Gournal Specific Fducation}

Faculty of Specific Fducation

gYansoura University

ISSUE NO. 21, APRIL. 2011

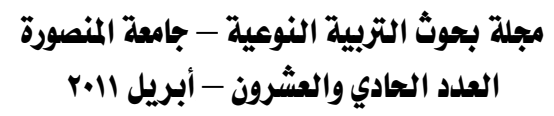




\title{
EFFECT OF SOME DRUGS AND HERBS ON EXPERIMENTAL RATS SUFFERING FROM OBESITY. \\ By
}

\author{
Farouk, M. El-Tellawy**; Atiat, M. El Bahay*; Abd El-Rahman, \\ M. Attia*; ASHRAF, A. Abd El-Megeid*; \\ and Abd El-Karim, I. Alhussain**. \\ * Nutrition and Food Science Department, Faculty of Home Economics, \\ Helwan University. \\ **Home Economics Department, Faculty of Specific Education, Ain \\ Shams University. Cairo-Egypt.
}

\section{Abstract}

The present study investigated the effect of some drugs (Orlistat and Chitosan) and herbs (Neopuntia and Jamu Tea) on weight, lipid fractions, glucose, liver function and kidney functions of obese rats fed on high fat diet. Healthy male albino rats weighing $(200 \pm 5 \mathrm{~g})$ were divided into two main groups. The first group $(n=6)$ fed on a basal diet B.D., while the second main group 30 rat were fed for 6 weeks on high fat diet to induce the obesity in rats. After these period, rats were divided into 5 subgroups $(n=6)$. As a following: Subgroup (1) fed on high fat and high protein diet (20\% fat and $20 \%$ protein) as a positive control. Subgroup (2) fed on high fat and high protein diet and treated daily with $5 \mathrm{mg}$ orlistat/ rat. Subgroup (3) fed on high fat and high protein diet and treated daily with $5 \mathrm{mg}$ chitosan/ rat. Subgroup (4) fed on high fat and high protein diet and treated daily with 5 mg Neopuntia / rat. Subgroup (5) fed on high fat and high protein diet and treated daily with $5 \mathrm{ml}$ Jamu tea / rat.

Body weight was decreased in all treated groups. All parameters of lipid profile (cholesterol, triglycerides, HDL-c, LDL-c and VLDL-c), liver function (AST \& ALT enzymes), glucose and kidney functions improved with treated the obese rats with Orlistat, Chitosan, Neopuntia and Jamu Tea, especially when using $5 \mathrm{mg}$ orlistat/ rat followed by $5 \mathrm{mg}$ chitosan / rat, and other herbs (Neopuntia and Jamu Tea), respectively. It was concluded that, treating obese rats which fed on high fat and high protein diet with Orlistat, Chitosan, Neopuntia and Jamu Tea decreased the weight of obese rats and improved the body functions.

Key words: rats, obese, Orlistat, Chitosan, Neopuntia, Jamu Tea, lipid profile, liver functions, glucose and kidney function. 


\section{EFFECT OF SOME DRUGS AND HERBS ON EXPERIMENTAL RATS SUFFERING FROM OBESITY. \\ By}

Farouk, M. El-Tellawy**; Atiat, M. El Bahay*; Abd El-Rahman, M. Attia*; ASHRAF, A. Abd El-Megeid*; and Abd El-Karim, I. Alhussain**.

* Nutrition and Food Science Department, Faculty of Home Economics, Helwan University.

**Home Economics Department, Faculty of Specific Education, Ain Shams University. Cairo-Egypt.

\section{Introduction:}

Over the past 20 years obesity has become a worldwide concern of frightening proportion. The World Health Organization estimates that there are over 400 million obese and over 1.6 billion overweight adults, a figure which is projected to almost double by 2015 . This is not a disease restricted to adults - at least 20 million children under the age of 5 years were overweight in 2005(

Obesity is a major public health concern because it increases the risk for many chronic conditions, such as cardiovascular diseases, diabetes, hypertension, coronary artery disease, and cancer (Zhang \&Reisin 2000; Lyznicki et al., 2001 and Calle et al., 2003).

Obesity is becoming a fast growing public health problem, and a high percentage of the population is facing this problem, especially in the developed countries. It can be successfully controlled by weight loss to reach the recommended ideal weight. Most obese patients are under cardiovascular risk factors (Lucas et al., 2003).

Dietary fat is considered to be one of the important environmental factors contributing to the obesity (Peters, 2003). Fat content is one of the main factors influencing the energy density of diets and an increase in energy density was shown to result in excess intake of calories; passive over consumption in humans in turn promotes the development of obesity (Westerterp-Plantenga, 2004).

Clinical intervention studies have provided sound evidence that an ad libitum high-protein diet from mixed sources in free-living overweight 
people increases the amount of weight lost in a 6-month weight-loss program (by $3.8 \mathrm{~kg}$ ), compared with a high-carbohydrate diet by enhancing satiety (Skov et al., 1999). A higher protein intake during weight loss may also prevent some of the inevitable loss of lean body mass and, thus, may enhance insulin sensitivity (Baba et al., 1999).

Different medications have been employed in the pharmacological treatment of obesity. Orlistat (tetrahydrolipstatin) is a covalent inhibitor of digestive lipases . Orlistat is derived from lipstatin, a natural product of Streptomyces toxytricini. It is an active site -directed inhibitor that reacts with the nucleophilic serine residue from the catalytic triad of pancreatic lipase (Tiss et al., 2002) . Orlistat helps to lose weight by inhibiting and subsequently preventing the digestion and absorption of dietary lipids. One of the side effects of orlistat is gastrointestinal symptoms. It caused increment of defecation, liquid and lipoid feces in 10-30\% of obese patients who took $360 \mathrm{mg} /$ day dose Orlistat (Joyce et al., 1998).

Chitocal (Chitosan) is an extraordinary fat binder and carbohydrate bluster. It is an amino polysaccharide that has the ability to bind the lipid in the intestine so it reduces the absorption of fat, by in return it reduces the blood lipid profile and prevents obesity and heart diseases (Keiji et al ., 1994). Under optimal conditions, Chitosan can bind an average of 8 to 12 times its weight with all the lipid aggregates tested (Nauss et al., 1993).

$\mathrm{NeOpuntia}$ is a natural fiber made from dehydrated leaves of a cactus (Opuntia ficus indica) . NeOpuntia is a complex of insoluble dietary fibers "Neofibers " and soluble polysaccharide dietary fibers " Neomicel " (Stintzing and Carle, 2005).

Jamu Tea is extracted from plant essence taken from roots, foliage, barks and other ingredients that contain vitamins and minerals which have traditionally been used in the Far East for centuries and have been passed on through generations. The ingredients of Jamu tea is from, folium extract (80\%), parameriae extract (6\%), guazumae extract $(6 \%)$, foeniculum vulgars (4\%), and curcumae extract (4\%) (Lily and Judith,1999).

Therefore, the present work was conducted to study the effect of Orlistat, Chitosan, Neopuntia and Jamu Tea, on weight loss, lipid profile, liver function, glucose and kidney functions of obese rats fed on high protein high fat diet. 


\section{MATERIALS AND METHODS:}

\section{Materials:}

- Casein, all vitamins, minerals, cellulose, L -Cystine and choline chloride were obtained from El-Gomhoriya company, Cairo, Egypt.

- Beef tallow, sucrose, starch and corn oil were obtained from local market, Cairo, Egypt.

- Xenical as source of Orlistat, chitocal as source of chitosan were obtained from the pharmacies, Cairo Egypt.

- NeOpuntia and Jamu Tea were obtained from local market, Saudi Arabia.

- Normal male albino rats (36) of Sprague Dawley Strain obtained from the Laboratory Animal Colony. Ministry of Health and Population, Helwan, Cairo, Egypt.

- Kits: kits used to determine serum cholesterol, triglycerides, LDL-c, HDL-c, VLDL-c, glucose , AST, ALT, uric acid, urea nitrogen, creatinine are obtained from Gama tread Company, Cairo, Egypt.

\section{Methods:}

\section{Preparation of Jamu tea:}

A Jamu Tea extracted according to the method described by (Jonathan et al., 2000), 3 bags from Jamu Tea will be extracted, by putting the tea bags, for $4 \mathrm{~min}$ in $250 \mathrm{ml}$ boiled water, then herbs beverages were extracted from the mixture after this step. Water extracts were prepared freshly every day.

\section{Biological Investigation:}

Male albino rats sprague Dawley Strain (36 rats) weighing (200 \pm 5 g) were housed in well aerated cages under hygienic condition and fed on basal diet for one week for adaptation. The basal diet consists of $14 \%$ protein from casein $(\geq 80 \%), 5 \%$ soya oil , $0.25 \%$ choline chloride, $1 \%$ vitamin mixture, $3.5 \%$ salt mixture, $5 \%$ cellulose, $0.18 \% \mathrm{~L}$ - cystine and the remainder $(71.07 \%)$ is corn starch (Reeves et al ., 1993). The salt mixture was prepared according to Hegested et al., (1941) and the vitamin mixture was prepared according to (A.O.A.C. 1975). 


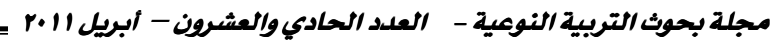

After adaptation period, the rats were divided into two main groups as follows : The first main group (6 rats) fed on basal diet (as a control negative group). The second main group (30 rat) was fed 6 week on high fat diet HFD containing (beef tallow $19 \%$, corn oil $1 \%$ to provide essential fatty acids, sucrose $10 \%$, casein $20 \%$, cellulose $5 \%$, vitamin mixture $1 \%$, salt mixture $3.5 \%$, choline chloride $0.25 \%$ and the remainder is corn starch) to induce obesity in rats (Min et al., 2004) to induce obesity.

After these periods, the mean value of body weight \% was estimated in the two main groups, also blood samples were collected from all rats to estimate the levels of cholesterol and triglycerides (healthy rats was $135.284 \pm 4.531 \mathrm{mg} / \mathrm{dl}$ cholesterol and $55.852 \pm 2.773 \mathrm{mg} / \mathrm{dl}$ triglycerides $)$, while the second main group recorded $(175.664 \pm 5.658 \mathrm{mg} / \mathrm{dl}$ cholesterol and $70.278 \pm 5.862 \mathrm{mg} / \mathrm{dl}$ triglycerides), then the rats were divided into five subgroups $(\mathrm{n}=6$ each) according to the following scheme: Subgroup (1) fed on high fat and high protein diet (20\% fat and $20 \%$ protein) as a positive control. Subgroup (2) fed on high fat and high protein diet and treated daily with $5 \mathrm{mg}$ orlistat/ rat. Subgroup (3) fed on high fat and high protein diet and treated daily with $5 \mathrm{mg}$ chitosan/ rat. Subgroup (4) fed on high fat and high protein diet and treated daily with $5 \mathrm{mg}$ Neopuntia / rat. Subgroup (5) fed on high fat and high protein diet and treated daily with 5 ml Jamu tea / rat.

During the experimental period ( 4 week), the diets consumed and body weights were recorded twice weekly.

At the end of the experiment, the animals were fasted overnight, then the rats were anaesthetized and sacrificed, and blood samples were collected from the aorta. The blood samples were centrifuged and serum was separated to estimate some biochemical parameters, i.e. serum cholesterol according to (Allain et al., 1974), triglycerids (Foster and Dumns, 1973), high density lipoprotein HDL-c (Lopes-Virella et al., 1977), low density lipoprotein LDL-c and VLDL-c (Fried Wald et al., 1972), aspartate amine transaminase (AST) and alanine amine transaminase (ALT) (Ritman and Frankel, 1957), glucose (Trinder 1959), uric acid (Fossati et al., 1980), urea nitrogen (Patton \& Crouch 1977) and creatinine Bohmer (1971).

Results of biological evaluation of each group were statistically analyzed (mean \pm standard deviation and one way ANOVA test) using 
SAS package and compared with each other using the suitable test (least significant differences at $\mathbf{P}<\mathbf{0 . 0 5}$. (SAS, 1996).

\section{Results and Discussion:}

Effect of some drugs and herbs on food intake and weights of obese rats.

The effect of some drugs (Orlistat and Chitosan) and herbs (Neopuntia and Jamu Tea) on food intake (g/day for each rat) and weights in obese rats are presented in table (1).

\section{Food intake (g/day for each rat).}

The mean value of food intake in health group fed on basal diet in (control -ve group) increased than that of obese group fed on diet containing $20 \%$ protein and $20 \%$ fat (17.857 vs. $16.369 \mathrm{~g} /$ day for each rat, respectively).

Food intake in obese groups which were treated with $(5 \mathrm{mg}$ orlistat/ rat), (5 mg chitosan / rat), (5 mg Neopuntia / rat) and (5 ml Jamu Tea / rat) had the lowest food intake, compared with the normal group (Control -ve group). The mean value of food intake in obese groups fed on diet containing (20\% protein and $20 \%$ fat) and treated with Orlistat and chitosan increased, while treated obese rats with neopuntia and jamu Tea led to decrease in the mean value of food intake as compared to the positive control group.

\section{Weights of rats $(\mathrm{g})$.}

Table (1) showed the follow-up development in weight of normal, obese and obese rats which were treating with orlistat, chitosan, neopuntia and jamu tea during the experiment. Data in this table showed significant decrease $(p<0.05)$ in the weight of normal group (control -ve group) in the initial of the experimental period, as compared to obese group (control +ve group) and obese groups which were treated with the two types of (drugs and herbs).

Feeding obese groups with diet containing $20 \%$ protein and $20 \%$ fat and treating with $(5 \mathrm{mg}$ orlistat/ rat), (5 mg chitosan / rat), (5 mg Neopuntia / rat) and $(5 \mathrm{ml}$ Jamu Tea / rat) led to significant decrease $(\mathrm{p}<0.05)$ in the weight at the medium and final of the experiment, as compared to the positive control group. On the other hand, all treated groups 
with drugs or herbs showed significant increase in the weight, as compared to the negative control group.

Group of rats which were treated with $(5 \mathrm{mg}$ orlistat/ rat), (5 mg chitosan / rat) recorded significant decrease $(\mathrm{p}<0.05)$ in the weight, as compared to treated groups with $(5 \mathrm{mg}$ Neopuntia / rat) and (5 ml Jamu Tea / rat).

\section{Body Weight Gain \% (BWG\%).}

Body weight gain $\%$ of obese rats fed on diet containing $20 \%$ protein and $20 \%$ fat (control $+v e$ ) increased significantly $p<0.05$, as compared to the negative control group fed on basal diet (Table 1). Treated groups with (5 $\mathrm{mg}$ orlistat/ rat) or (5 $\mathrm{mg}$ chitosan / rat) resulted in the highest decrease in BWG\%, as compared to (control +ve) and other treated groups.

In this respect, (Wickelgren, 1998) defined the obesity, as an increase in mass of adipose tissue, confers a higher risk for metabolic diseases such as non-insulin-dependent diabetes, cardiovascular disease, and stroke and an increased incidence of morbidity.

Sjostrom et al., (1998) showed that orlistat is minimally $(<1 \%)$ absorbed from the gastrointestinal tract, promotes significant weight loss when used in conjunction with a mildly hypoenergetic diet, and lowers blood lipid concentrations. On the other hand, David,( 2003) reported that, orlistat is the only approved inhibitor of the gastrointestinal lipases, predominantly pancreatic lipase, necessary for the hydrolysis of triglyceride to free fatty acids in the lumen of the gut. Because this agent can reduce the absorption of dietary fat by up to $30 \%$, it produces weight loss comparable to or greater than that obtained by placing an individual on a fat-restricted diet.

Chitosan is an aminopolysacharide, derived from "Chitin". Chitin is found in plankton and the exoskeletons (shells) of crustaceans such as shrimp, lobster or crab. Researchers have been doing clinical studies on chitosan as a natural weight loss agent and as a fiber for adding bulk to the digestive system and for colon cleaning (Shahram, 1992). Our results agree with Abelin and Lassus (1994) who showed that individuals taking chitosan lost an average of 8 percent of their body weight in a 4-week period. 
Ennouri et al., (2005) evaluate some biological parameters in rats fed with a supplemented diet with Opuntia ficus indica powder seeds. Feed intake and body weight of rats were measured every two days during nine weeks of treatment. The results indicated a significant decrease in body weight of rats receiving a diet partially substituted with $O$. ficus indica powder seeds, probably due to a significant decrease in serum-free thyroxin $\left(\mathrm{FT}_{4}\right)$ compared to the control group.

Green tea in the presence of Jamu Tea is a metabolic stimulant and has been used for weight loss, its polyphenol content acids in body fat loss; prevents free-radical damage ; is an anticoagulant ; lowers LDL cholesterol and raises HDL ; lowers blood cholesterol ; maintains blood sugar levels and reduces the effects of food poisoning (Kirschmann , 1996).

Merina , (2005) reported that, Standardized green tea extract is found to be very effective for reducing obesity and abdominal fat in human volunteers. The other advantage of standardized extracts is that the dosage can be defined. The average dosage of green tea extract is $500-1500 \mathrm{mg} / \mathrm{day}$.

\section{Effect of some drugs and herbs on lipid profile ( $\mathrm{mg} / \mathrm{dl})$ of obese rats.}

The effect of some drugs (orlistat and chitosan) and herbs (neopuntia and Jamu tea) on serum cholesterol and triglycerides on obese rats are presented in table (2). The data in this table showed that, total cholesterol in obese rats fed on diet containing $20 \%$ protein and $20 \%$ fat increased the mean value of serum cholesterol significantly $\mathrm{p}<0.05$, as compared to healthy rats fed on basal diet (control -ve group). Feeding obese group on a diet containing ( $20 \%$ protein \& $20 \%$ fat) and treated with $(5 \mathrm{mg}$ orlistat/ rat), (5 mg chitosan / rat) and (5 mg neopuntia / rat) resulted in decrease in total cholesterol, while treated rats with $(5 \mathrm{ml}$ Jamu Tea / rat) showed nonsignificant differences, as compared to the positive control group.

Treating obese rats which fed on diet containing (20\% protein \& $20 \%$ fat) with orlistat achieved the highest decrease in serum cholesterol, as compared to other tested groups.

Table (2) illustrated that, feeding obese rats on diet containing $20 \%$ protein and $20 \%$ fat increased serum triglycerides and VLDL-c significantly $\mathrm{p}<0.05$, as compared with the negative control group. Serum triglycerides and VLDL-c in obese groups fed on diet containing (20\% protein \& $20 \%$ fat) and (treated with orlistat, chitosan and neopuntia) decreased significantly $\mathrm{p}<0.05$, while treated obese rats with jamu tea showed 
nonsignificant changes in this parameter, as compared to the positive control group.

The highest decrease in serum triglycerides and VLDL-c recorded for the treated group with chitosan, following by orlistat, while the lowest decrease in this parameter recorded for the treated group neopuntia and jamu tea.

Untreated obese rats fed on diet containing $20 \%$ protein and $20 \%$ fat (control +ve group) revealed significant decrease $\mathrm{p}<0.05$ in the mean value of serum HDL-c, compared with the healthy group fed on basal diet. Data in this table showed that, feeding obese rats on diet containing (20\% protein and $20 \%$ fat) and treated daily with (5 mg orlistat/ rat, $5 \mathrm{mg}$ chitosan / rat, 5 $\mathrm{mg}$ neopuntia / rat or $5 \mathrm{ml} \mathrm{Jamu} \mathrm{Tea} \mathrm{/} \mathrm{rat)} \mathrm{led} \mathrm{to} \mathrm{significant} \mathrm{increase} \mathrm{p}<0.05$ in the mean value of serum HDL-c, as compared to the positive control group.

The best results in HDL-c recorded for the group fed on diet containing (20\% protein and $20 \%$ fat) and treated daily with (5 mg chitosan / rat), followed by the groups which treated daily with $(5 \mathrm{mg}$ orlistat/ rat and $5 \mathrm{mg}$ neopuntia / rat), respectively.

Low density lipoprotein cholesterol LDL-c, increased significantly in the positive control group fed on diet containing (20\% protein and $20 \%$ fat), as compared to the negative control group fed on basal diet. Results in this table revealed that, all treated groups with $(5 \mathrm{mg}$ orlistat/ rat, $5 \mathrm{mg}$ chitosan / rat, $5 \mathrm{mg}$ neopuntia / rat or $5 \mathrm{ml}$ Jamu Tea / rat) decreased the mean value of serum LDL-c, as compared to the positive control group.

Treating obese rats daily with $(5 \mathrm{mg}$ orlistat/ rat, $5 \mathrm{mg}$ chitosan / rat and $5 \mathrm{mg}$ neopuntia / rat) led to decrease the mean value of LDL-c by about $(17.708 \mathrm{mg} / \mathrm{dl}$ to $20.825 \mathrm{mg} / \mathrm{dl}$ ), than that of the positive control group.

From our results, it could be observed that, treating obese rats with Orlistat, chitosan, neopuntia and jamu tea improved the lipid fractions. In this respect, Pi-Sunyer (1996) reported that, improvement in concentrations of cholesterol and triacylglycerols resulted from therapy with orlistat. As a result of its effect on the body's ability to absorb dietary fats, orlistat is known to be associated with an increased incidence of gastrointestinal events in its users. 
Orlistat is a gastric and pancreatic lipase inhibitor that alters energy balance by reducing the absorption of triglyceride and cholesterol from the gastrointestinal tract (Mittendorfer et al., 2001). In adults, orlistat, at the standard dose of $120 \mathrm{mg}$ three times daily, inhibits $\approx 30 \%$ of triglyceride absorption (Guerciolini, 1997).

In placebo-controlled studies, adults treated with orlistat for periods as long as 2 years exhibited greater average weight loss, better weight maintenance, lower total and low density lipoprotein-cholesterol (LDLcholesterol), and improved glycemic control for patients with type 2 diabetes (Rossner et al., 2000). Also (Zhi et al., 1994 and Muls et al., 2001) reported that, during weight loss, orlistat reduced fat absorption, as shown by a decrease in serum LDL cholesterol that was expected, and that corresponds to an $\approx 25 \%$ decrease in cholesterol absorption and a $30 \%$ decrease in fat absorption.

Macchi (1996) demonstrated that chitosan is useful in the treatment of obesity because it enhances the loss of body fat and acts to normalize plasma cholesterol and triglycerides levels, possibly with an increase of HDL-cholesterol. Greater effects are obtained when chitosan is associated with a hypocaloric diet.

One clinical study showed that in five weeks, total cholesterol as reduced by a whopping 32\% when using chitosan (Kobayashi et al., 1999). Another study showed that rats fed chitosan had decreased liver cholesterol levels 60\% lower than the control group after 4 weeks (Sugano et al., 1998).

Alternatively, it is possible that the cholesterol-lowering effect of chitosan is due to an increase in the viscosity of intestinal contents. Increased intestinal contents supernatant viscosity is highly correlated with reduced plasma and liver cholesterol (Gallaher et al. 1993 ${ }^{\mathrm{a}}$ and $1993^{\mathrm{b}}$ ) and reductions in cholesterol absorption (Carr et al. 1996 ) in hamsters. Recently, chitosan (CS) has been examined as an alternative therapy, since oral administration of CS leads to decreased serum cholesterol levels (Ylitalo et al., 2002).

The consumption of fresh or dehydrated leaves of Opuntia ficusindica has been studied in animal models, in order to evaluate the effects on lipid metabolism. One of the first studies was performed on laboratory rats, showing that consumption of Opuntia ficus-indica induced a decrease in 
low-density lipoprotein cholesterol (LDL-C) levels of 34\%, without affecting high-density lipoprotein cholesterol (HDL-C) levels (Cardenas et al., 1998) . A more recent study demonstrated, a significant reduction in cholesterol, LDL-C, and triglyceride plasma levels in hypercholesterolemic rats following daily administration of lyophilized leaves of Opuntia ficusindica (Galati et al.,2003).

The green tea and curcumin presented on Jamu tea affect on lipid metabolism. In this respect, Yuan et al.,(2006) studied The anti-obesity and lipid-lowering effects of green tea consumption in middle-aged adults. A total of 3317 individuals were included. Consumption of green tea significantly decreased serum total cholesterol $(\mathrm{p}<0.01)$, low density lipoprotein $(\mathrm{P}<0.01)$ and triglycerides $(\mathrm{P}<0.01)$; the incidence of obesity was also lowered by green tea consumption $(\mathrm{P}<0.05)$. The relation was enhanced after adjusting for age, sex, smoking habits, alcohol intake and exercise time.

Effect of some drugs and herbs on serum glucose and liver enzymes of obese rats.

\section{Serum glucose $(\mathbf{m g} / \mathrm{dl})$.}

The effect of some drugs (orlistat and chitosan) and herbs (Neopuntia and Jamu tea) on serum glucose $(\mathrm{mg} / \mathrm{dl}$ ) and AST \& ALT enzymes (U/L) on obese rats are presented in table (3). The data in this table showed that, serum glucose in obese rats fed on diet containing $20 \%$ protein and $20 \%$ fat increased significantly $\mathrm{p}<0.05$, as compared to healthy rats fed on basal diet.

Feeding obese group on a diet containing (20\% protein \& $20 \%$ fat) and treated daily with $(5 \mathrm{mg}$ orlistat/ rat), (5 mg chitosan / rat), (5 mg Neopuntia / rat) and ( $5 \mathrm{ml} \mathrm{jamu} \mathrm{tea/rat)} \mathrm{resulted} \mathrm{in} \mathrm{decrease} \mathrm{the} \mathrm{mean} \mathrm{value}$ of serum glucose, as compared to the positive control group. On the other hand, statistical analysis revealed that, treating obese rats daily with $(5 \mathrm{mg}$ orlistat or $5 \mathrm{mg}$ chitosan / rat) led to significant decrease $\mathrm{p}<0.05$, as compared to treated groups with (5 mg neopuntia / rat or $5 \mathrm{ml} \mathrm{jamu} \mathrm{tea/rat).}$

\section{Aspartate and Alanine Amine Transaminase AST\& ALT (U/L) :}

Table (3) illustrated that, feeding obese rats on diet containing $20 \%$ protein and $20 \%$ fat increased serum AST \& ALT enzymes significantly 
$\mathrm{p}<0.05$, as compared with the negative control group $(20.333 \pm 2.251$ and $7.667 \pm 0.517)$ vs. $(15.667 \pm 1.211$ and $6.167 \pm 0.753)$, respectively.

Serum AST enzymes in all obese groups fed on diet containing (20\% protein \& $20 \%$ fat) and treated daily with (orlistat, chitosan, neopuntia and jamu tea) decreased significantly $\mathrm{p}<0.05$, as compared to the positive control group. On the other hand, all tested groups which treated with drugs or herbs recorded nonsignificant differences in AST enzymes, except group of rats which treated with chitosan, as compared to the negative control group.

Concerning ALT enzymes. The results indicated that, some treatment showed nonsignificant changes in ALT enzymes, as compared to the negative and positive control groups such as, (the treatment with chitosan and neopuntia), while other treatment showed significant decrease $\mathrm{p}<0.05$ in ALT, as compared to the positive control group i.e. (orlistat and jamu tea).

In this respect, (Steven et al.,2000) reported that, the addition or orlislat to a conventional weight loss regimen significantly improved oral glucose tolerance and diminished the rate or progression to the development of impaired glucose tolerance and type 2 diabetes.

Sugiyama et al., (1999), who reported that feeding rats on diet supplemented with the powder of green tea GT extract showed a significant decrease in serum AST and ALT compared with control. Studies by Arteel et al., (2002) also noted that there was a significant lowering in the activities of AST and ALT in rats treated with GT extract in the diet. Recently, curcumin has been considered a potentially important chemopreventive agent against cancer and raising the possibility that it might be useful in preventing alcoholic liver disease (Shukla \& Arora 2003 and Amin et al., 2003 ).

\section{Effect of some drugs and herbs on kidney function of obese rats.}

The effect of some drugs (orlistat and chitosan) and herbs (neopuntia and Jamu tea) on serum uric acid, urea nitrogen and creatinine $(\mathrm{mg} / \mathrm{dl})$ of obese rats are presented in table (4). 


\section{Uric acid (mg/dl).}

The data in this table showed that, serum uric acid in obese rats fed on diet containing $20 \%$ protein and $20 \%$ fat increased significantly $\mathrm{p}<0.05$, as compared to healthy rats fed on basal diet (control -ve group).

Feeding obese groups on a diet containing (20\% protein \& $20 \%$ fat) and treated daily with $(5 \mathrm{mg}$ orlistat/ rat), ( 5 chitosan/ rat), (5 mg neopuntia $/$ rat $)$ and $(5 \mathrm{ml} \mathrm{jamu} \mathrm{tea/rat)} \mathrm{led} \mathrm{to} \mathrm{significant} \mathrm{decrease}(\mathrm{p}<0.05)$ in the mean value of serum uric acid, as compared to the positive control group. Statistical analysis in this table revealed that, the lowest mean value of serum uric acid recorded for the treated obese rats daily with $(5 \mathrm{mg}$ orlistat/ rat), followed by the groups treated with (5 chitosan/ rat) and (5 mg neopuntia / rat), while the highest mean value of serum uric acid recorded for the group treated daily with $(5 \mathrm{ml} \mathrm{jamu} \mathrm{tea/rat)}$.

\section{Urea nitrogen (mg/dl).}

Table (4) illustrated that, feeding obese rats on diet containing $20 \%$ protein and $20 \%$ fat increased serum urea nitrogen significantly $\mathrm{p}<0.05$, as compared with the negative control group. Serum urea nitrogen in all obese groups fed on diet containing ( $20 \%$ protein \& $20 \%$ fat) and treated daily with (orlistat, chitosan, neopuntia and jamu tea) decreased significantly $\mathrm{p}<0.05$, as compared to the positive control group. On the other hand nonsignificant differences in serum urea nitrogen were observed between all treated obese groups with drugs and herbs used in this study.

\section{Creatinine (mg/dl).}

The comparison between the negative control group (- ve), the positive control groups (obese group fed on diet containing 20\% protein and $20 \%$ fat) and treated obese groups with orlistat, chitosan, neopuntia and jamu tea in the levels of serum creatinine, are summarized in table (4). All treated obese groups with the drugs or herbs used in this study showed significant decrease $p<0.05$ in serum creatinine, as compared to the positive control group. The highest decrease in serum creatinine recorded for the groups treated daily with (5 mg orlistat/ rat) and (5 chitosan/ rat), followed by other treated groups.

Henegar et al., (2001) reported that, obesity and high-fat diets are linked with kidney dysfunction in rats and dogs. Also Jing, et al., (2003) confirm that high dietary fat worsens early disease progression in this model 
of renal disease, and further demonstrate that diets with oils containing (n-3) fatty acids ameliorate some of the detrimental effects of a high fat diet.

The effects of chitosan have been investigated on eighty patients with renal failure undergoing long-term stable haemodialysis treatment. The patients were fed 30 chitosan ( $45 \mathrm{mg}$ chitosan/tablet) three times a day. Significant reductions In urea and creatinine levels in serum were observed after a weeks of chitosan ingestion. The feeling of physical strength, the appetite and the sleep of patients in the treatment group had improved significantly after 12 weeks of ingestion, compared with those of patients in the control group (Jing et al., 1997).

Yokozawa et al. (2003) reported that green tea GT polyphenol is effective against renal failure in rats. GT polyphenol administered to rats at a daily dose of 50 or $100 \mathrm{mg} / \mathrm{kg}$ body weight for 30 days with a $2 \%$ arginine diet decreased serum levels of creatinine and urea nitrogen. The protective effect can be attributed to a decrease in uremic toxins and nitric oxide production and an increase in the renal activities of the oxygen speciesscavenging enzymes, superoxide dismutase and catalaze. 


\section{References:}

- Abelin, J. and Lassus, A. (1994). Fat Binder as a Weight Reducer in Patients with Moderate Obesity. ARS Medicina, Helsinki, AugOctober, 1994.

- Allain, C.; Poon, L. and Chan, C. (1974): Enzymatic determination of total serum cholesterol. Clin. Chem., 20:470-475.

- Amin A. N.; Kalle, J.; George, L. T.; Amir, R.; Peter, T. and Andrew, J. D. (2003). Curcumin prevents alcohol-induced liver disease in rats by inhibiting the expression of NF-B-dependent genes. Am. $J$. Physiol. Gastrointest. Liver Physiol., 284 (2): G321-G327.

- A.O.A.C. (1975). Official Methods of Analysis of the Assoc. of Official Agricultural Chemists, $12^{\text {th }}$ ed. Washington, D. C.

- Arteel, G.E.; Uesugi, T. ; Bevan, L.N.; Gabele, E.; Wheeler, M.D.; Mckim, S.E. and Thurman, R.G. (2002). Green tea extract protects against early alcoholinduced liver injury in rats. Biol. Chem., 383(34):663-670.

- Baba, N.H.; Sawaya, S.; Torbay, N.; Habbal, Z.; Azar, S. and Hashim, S.A. (1999). High protein vs. high carbohydrate hypoenergetic diet for the treatment of obese hyperinsulinemic subjects. Int. J. Obes.Relat. Metab. Disord.,23:1202-1206.

- Bohmer, H.B.U.M. (1971). Micro-determination of creatinine. Clin.Chem. Acta, 32: 81-85.

- Calle, E.E.; Rodriquez, C.; Walker-Thurmond, K. and Thun, M.J. (2003): Overweight, obesity, and mortality from cancer in a prospectively studied cohort of U.S. adults. $N$ Engl J Med, 348, 1625 1638.

- Cardenas, M.L.; Sena, S.O. and Velazco, J. (1998). Effect of raw and cooked nopal (Opuntia ficus indica) ingestion on growth and profile of total cholesterol; lipoproteins, and blood glucose in rats [in Spanish]. Arch Latinoam Nutr.,48:316-323.

- Carr, T. P.; Gallaher, D. D.; Yang, C.H. and Hassel, C. A. (1996). Intestinal contents viscosity and cholesterol absorption efficiency in hamsters fed hydroxypropyl methylcellulose. J. Nutr., 126:1463-1469. 
- David, S. W. (2003). Pharmacological therapy of obesity: Past, present, and future. J. Clinical Endocrinology \& Metabolism, 88 (6): 24622469.

- Ennouri, M.; Fetoui, H; Bourret, E.; Zeghal, N.; Guermazi, F. and Attia, H. (2005). Evaluation of some biological parameters of Opuntia ficus indica. 2. Influence of seed supplemented diet on rats. Bioresource Technology 97 (16): 2136-2140.

- Fossati, P.; Prencipe, L. and Berti, G. (1980). Enzymatic colorimetric method of determination of uric acid in serum. Clin. Chem. 26 (2): $227-$ 273.

- Foster, L. B. and Dumns, T. T. (1973): Determination of triglycerides. J. Clin. Chem., 19:338-353.

- Fried Wald ،W. T.; Leve, R. I. and Fredrickson, D. S. (1972). Estimation of the concentration of low-density lipoprotein separation by three different methods . Cli. Chem., 18: 499-502.

- Galati, E.M.; Tripodo, M.M.; Trovato, A.; Aquino, A. and Monforte, M.T. (2003). Biological activity of Opuntia ficus indica Cladodes II: Effect on experimental hypercholesterolemia in rats. Pharm. Biol., 41:175-179.

- Gallaher, D. D.; Hassel, C. A. and Lee, K.J. (1993) ${ }^{\mathbf{a}}$. Relationships between viscosity of hydroxypropyl methylcellulose and plasma cholesterol in hamsters. J. Nutr.,123:1732-1738.

- Gallaher, D. D.; Hassel, C. A. and Lee, K.J. $(1993)^{\text {b }}$. Viscosity and fermentability as attributes of dietary fiber responsible for the hypocholesterolemic effect. J. Nutr., 123:244-252.

- Guerciolini, R. (1997). Mode of action of orlistat. Int. J. Obes. Relat. Metab. Disord., 21(Suppl 3):S12-S23.

- Hegested, D.M.; Mills, C.; Elvehjem, C.A. and Hart, E.B. (1941). Choline in the nutrition of chicks. J. Biol. Chem., 138: 459-470.

- Henegar, J.R.; Bigler, S.A.; Henegar, L.K.; Tyagi, S.C. and Hall, J.E. (2001). Functional and structural changes in the kidney in the early stages of obesity. J. Am. Soc. Nephrol., 12:1211-1217. 
- Jing, L.u.; Neda, B.; Malcolm, O.M.; Hossein, S. and Harold, M. A. (2003). Detrimental effects of a high fat diet in early renal injury are ameliorated by fish oil in Han: SPRD-cy Rats. J. Nutr., 133:180-186.

- Jing, S. B.; Li, L.; Ji, D.; Takiguchi, Y. and Yamaguchi, T. (1997). Effect of chitosan on renal function in patients with chronic renal failure. J. Pharm. Pharmacol., 49(7): 721-723.

- Jonathan, M.H.; Ian, B. P.; Kevin, D. C.; Valerie, B.; Trevor, A. M.Rima, A. C. and Lawrence, J. B. (2000): Acute effects of ingestion of black and green tea on lipoprotein oxidation. Am. J. Clin. Nutr., 71 (5): 1103-1107.

- Joyce, B. Harp. (1998). An assessment of the efficacy and safety of Orlistat for long-term management of obesity. J. Nutr. Biochem., 9: 516521.

- Keiji, D.; Osamu, K. and Youji, I. (1994). Decreasing effect of chitosan on the apparent fat digestibility by rats fed on a high - fat diet. Biosci. Biltech. Biochem., 58: 1613- 1616.

- Kirschmann, G. J. (1996) . Nutrition Almanac . $4^{\text {th }}$ ed . Mc Graw .Hill . New York, USA, $337-355$.

- Kobayashi, T,; Otsuka, S. and Yugari, Y. (1999). Effect of chitosan on serum and liver cholesterol levels In cholesterol-fed rats. Nutritional Rep. Int.,19(3):327-334.

- Lily, M. P. and Judith, M. M. (1999). Plants of East and Southeast Asia : Attributed Properties and uses. The MIT press, Cambridge , London, England.

- Lopes-Virella, M. F.; Stone, S.; Ellis, S. and Collwellm J. A. (1977): Cholesterol determination in high-density lipoproteins separated by three different methods. Clin. Chem., 23 (5): 882-893.

- Lucas, C.P.; Boldrin, M.N. and Reaven, G.M. (2003). Effect of Orlistat added to diet (30\% of calories from fat) on plasma lipids, glucose and insulin in obese patients with hypercholesterolemia. Am. J. Cardiol., 91: 961-964.

- Lyznicki, J. M.; Young, D. C.; Riggs, J. A.; Davis, R. M. (2001): Obesity: assessment and management in primary care. Am Fam Physician, 2001, 63, 2185-2196. 
- Macchi, G. (1996). A new approach to treatment of obesity: Chitosan's effects on body weight reduction and plasma cholesterol's levels. Acta Toxicol. Ther., 17:303-320.

- Merina, B. (2005). Value added products from green tea. NaturalProduct-Radiance.; 4(3): 177-178.

- $\quad$ Min, L.; Ling, S.; Yin, L.; Stephen, C.W.; Randy, J. S.; David, D. and Patrick, T. (2004). Obesity induced by a high-fat diet downregulates apolipoprotein A-IV gene expression in rat hypothalamus. Am. J. Physiol. Endocrinol Metab.,287: E366-E370.

- Mittendorfer, B.; Ostlund, R.J.; Patterson, B. and Klein, S. (2001). Orlistat inhibits dietary cholesterol absorption. Obes. Res., 9:599-604.

- Muls, E.; Kolanowski, J.; Scheen, A. and Van Gaal, L. (2001). The effects of orlistat on weight and on serum lipids in obese patients with hypercholesterolemia: a randomized, double-blind, placebo-controlled, multicentre study. Int. J. Obes. Relat Metab. Disord., 25:1713-1721.

- Nauss, J.L. ;Thompson, J. L. and Nagyvary, J. (1993). The binding of micellar lipids to Chitosan Lipids. Lipids 18:714-719.

- Patton, C.J. and Crouch, S.R. (1977). Enzymatic colorimetric method to determination urea in serum. Anal. Chem., 49: 464.

- Peters, J. C. (2003). Dietary fat and body weight control. Lipids, 38:123-127.

- Pi-Sunyer, F.X. (1996). A review of long-term studies evaluating the efficacy of weight loss in ameliorating disorders associated with obesity. Clin. Ther., 18:1006-1035.

- Reeves, P. G.; Nielsen, F. H. and Fahmy, G. C. (1993). AIN-93 purified diets for laboratory rodents: Final report of the American Institute of Nutrition ad hoc writing committee on the reformulation of the AIN-76A rodent diet. J. Nutr.,123(11):1939-1951.

- Ritman, S. and Frankel, S. (1957): Determination of glutamate pyruvate transferase. Am. J. Clin. Path., 28:56.

- $\quad$ Rossner, S.; Sjostrom, L.; Noack, R.; Meinders, A.E. and Noseda, G. (2000). Weight loss, weight maintenance, and improved cardiovascular risk factors after 2 years treatment with orlistat for obesity; European Orlistat Obesity Study Group. Obes. Res ., 8: 49-61. 
- Shahram, H. (1992). Seafood waste: The potential for industrial use. Kem Kemi;19(3)256-258.

- Shukla, Y. and Arora, A. (2003). Suppression of altered hepatic foci development by curcumin in wistar rats. Nutr. Cancer, 45(1): 53-59.

- Sjostrom, L.; Rissanen, A. and Andersen, T. (1998). Randomised placebo-controlled trial of orlistat for weight loss and prevention of weight regain in obese patients. Lancet, 352:167-173.

- Skov, A.R.; Toubro, S.; Ronn, B.; Holm, L. and Astrup, A. (1999). Randomized trial on protein vs carbohydrate in ad libitum fat reduced diet for the treatment of obesity. Int. J. Obes. Relat. Metab. Disord.,23:528-536.

- Steven, B.; Heymsfield, S.; Karen, M.; Segal, R.; Jonathan, M. and Charles, P. (2000). Effects of weight loss with orlistat on glucose tolerance and progression to type 2 diabetes in obese adults. Arch Intern Med., 160:1321-1326

- SAS, (1996): "Statistical Analysis System" SAS User's Guide: Statistics. SAS Institute Inc. Editors, Cary, NC.

- Stintzing, P. and Carle, R. (2005). Cactus stems (Opuntia spp.): a review on their chemistry, technology, and uses. Mol. Nutr. Food Res., 49:175-194.

- Sugano, M.; Fujikawa, T.; Hiratsuji, Y. and Hasegawa, Y. (1998): Hypocholesterolemic effects of chitosan in cholesterol fed rats. Nutr Rep . Int., (5):531-537.

- Sugiyama, K., P. He, S. Wada and S. Saeki, (1999). Teas and other beverages suppress DGalactosamine- induced liver injury in rats. $J$. Nutr., 129: 1361-1367.

- Tiss, A.; Lengsfeld, H.; Hardvary, P.; Cagna, A. and Verger, R. (2002). Transfer of orlistat through oil-water interfaces. Chem. Physic. Lipids, 119: 41-49.

- Trinder, P. (1959). Determination of blood glucose using 4aminophenazone. J. Clin. Path., 22: 246.

- Westerterp-Plantenga, M. S. (2004). Effects of energy density of daily food intake on long-term energy intake. Physiol. Behav., 81:765-771.

- Wickelgren, I. (1998). Obesity: How big a problem? Science, 280 :1364-1367. 
- Zhang, R.; Reisin, E. (2000): Obesity-hypertension: the effects on cardiovascular and renal systems. Am J Hypertens, 2000, 13, 1308-1314.

- WHO. Obesity and overweight fact sheet. 2006. Sep,

- Ylitalo, R.; Lehtinen, S.; Wuolijoki, E.; Ylitalo, P. and Lehtimaki, T. (2002). Cholesterol-lowering properties and safety of chitosan. Arzneimittelforschung, 52: 1-7.

- Yokozawa, T., E. Cho and T. Nakagawa, (2003): Influence of green tea polyphenol in rats with arginine-induced renal failure. J. Agric. Food Chem., 51: 2421-2425.

- Yuan,Y.; Tian,Y.; Xiao,Y.; and Yu, S. (2006). Green tea consumption prevents hypercholesterolemia and obesity. Acta-Nutrimenta-Sinica.; 28(3): 230-232.

- Zhi, J.; Melia, A.T.; Guerciolini, R.; Chung, J.; Kinberg, J.; Hauptman, J.B. and Patel, I.H. (1994). Retrospective populationbased analysis of the dose-response (fecal fat excretion) relationship of orlistat in normal and obese volunteers. Clin. Pharmacol. Ther., 56: 8285 . 


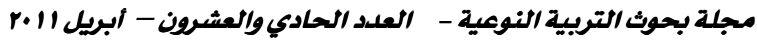

Table (1): Effect of some drugs and herbs on food intake and weights of obese rats.

\begin{tabular}{|c|c|c|c|c|c|c|}
\hline \multirow{2}{*}{\multicolumn{2}{|c|}{ Groups }} & \multirow{2}{*}{$\begin{array}{l}\text { Food } \\
\text { Intake } \\
\text { (g/day) }\end{array}$} & \multicolumn{3}{|c|}{ Weight in the } & \multirow[b]{2}{*}{ BWG\% } \\
\hline & & & $\begin{array}{c}\begin{array}{c}\text { Initial of } \\
\text { the } \\
\text { experiment }\end{array} \\
\end{array}$ & $\begin{array}{l}\text { Mid of the } \\
\text { experiment }\end{array}$ & $\begin{array}{l}\text { Final of the } \\
\text { experiment }\end{array}$ & \\
\hline \multicolumn{2}{|c|}{ Control (-ve ) } & $I V, \wedge O V$ & $\begin{array}{l}213.50^{\mathbf{b}} \\
\pm 5.010\end{array}$ & $\begin{array}{r}234.6 \\
\pm 4.9\end{array}$ & $\begin{array}{c}254 \\
\pm\end{array}$ & $\begin{array}{l}19.147^{\mathbf{c}} \\
\pm 3.688\end{array}$ \\
\hline \multicolumn{2}{|c|}{\begin{tabular}{|c|} 
Obese rats (+ve) \\
fed on diet \\
containing $20 \%$ \\
Protein and $20 \%$ \\
Fat \\
\end{tabular}} & 17,479 & $\begin{array}{c}259.333^{\mathrm{a}} \\
\pm 5.922\end{array}$ & $\begin{array}{r}304 \\
\pm 6\end{array}$ & $\begin{array}{r}356 \\
\pm 8\end{array}$ & $\begin{array}{l}37.550^{\mathrm{a}} \\
\pm 2.512\end{array}$ \\
\hline \multirow{4}{*}{  } & Orlistat & 17,774 & $\begin{array}{c}259.000^{\mathrm{a}} \\
\pm 9.960\end{array}$ & $\begin{array}{l}274.500^{c} \\
\pm 10.483\end{array}$ & $\begin{array}{l}289.333^{c} \\
\pm 11.039\end{array}$ & $\begin{array}{c}11.718^{\mathrm{d}} \\
\pm 1.230\end{array}$ \\
\hline & Chitosan & $17,0 \leq V$ & $\begin{array}{l}260.667^{\mathrm{a}} \\
\pm 12.723\end{array}$ & $\begin{array}{l}279.667^{\mathrm{c}} \\
\pm 11.075\end{array}$ & $\begin{array}{l}297.167^{\mathbf{c}} \\
\pm 13.182\end{array}$ & $\begin{array}{l}14.073^{d} \\
\pm 3.723\end{array}$ \\
\hline & Neopuntia & $|7, \cdot V|$ & $\begin{array}{c}259.333^{\mathrm{a}} \\
\pm 8.140\end{array}$ & $\begin{array}{c}293.167^{\text {ab }} \\
\pm 10.477\end{array}$ & $\begin{array}{l}318.667^{\mathbf{b}} \\
\pm 12.832\end{array}$ & $\begin{array}{l}22.903^{b} \\
\pm 4.113\end{array}$ \\
\hline & Jamu & $10, \mathrm{VV}$ & $\begin{array}{c}260.000^{\mathrm{a}} \\
\pm 8.222 \\
\end{array}$ & $\begin{array}{c}291.833^{\mathrm{b}} \\
12.303 \\
\end{array}$ & $\begin{array}{l}318.605^{\mathbf{b}} \\
\pm 11.832 \\
\end{array}$ & $\begin{array}{c}22.550^{\mathbf{b c}} \\
\pm 2.317 \\
\end{array}$ \\
\hline
\end{tabular}

Values are expressed as mean $\pm S D . \quad$ Significance at $p<0.05 . B W G \%$ :

Body weight gain \%.

Values which don't share the same letter in each column are significantly different. 
Table (2): Effect of some drugs and herbs on lipid profile of obese rats.

\begin{tabular}{|c|c|c|c|c|c|c|}
\hline \multirow{2}{*}{\multicolumn{2}{|c|}{$\begin{array}{l}\text { Parameters } \\
\text { Groups }\end{array}$}} & \multicolumn{5}{|c|}{$\overline{\mathrm{mg} / \mathrm{dl}}$} \\
\hline & & Chol & TG & HDL-c & LDL-c & VLDL-c \\
\hline \multicolumn{2}{|c|}{$\begin{array}{c}\text { Normal rats (-ve) fed } \\
\text { on basal diet. }\end{array}$} & $\overline{163}$ & $\begin{array}{l}1.933^{d} \\
2.070\end{array}$ & $\overline{\mathrm{ac}}$ & & \\
\hline \multicolumn{2}{|c|}{$\begin{array}{c}\text { Obese rats (+ve) fed } \\
\text { on diet containing } \\
20 \% \text { Protein and } \\
20 \% \text { Fat. } \\
\end{array}$} & $\begin{array}{r}19 \\
\pm\end{array}$ & & & $37^{\mathrm{a}}$ & \\
\hline \multirow{4}{*}{ 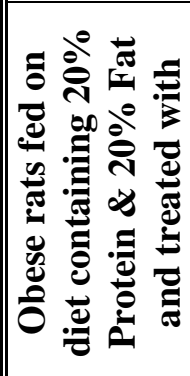 } & 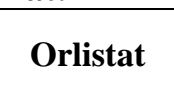 & $\begin{array}{r}180 . \\
\pm 3\end{array}$ & $\begin{array}{l}\text { 81.892 }^{c} \\
\pm 3.445\end{array}$ & $\begin{array}{r}\mathbf{5 0 .} \\
\pm 1\end{array}$ & & \\
\hline & $\mathrm{Cl}$ & $\begin{array}{r}182 . \\
\pm 2\end{array}$ & $\begin{array}{l}74.883^{d} \\
\pm 2.852\end{array}$ & & & \\
\hline & Neo & $\begin{array}{r}186.4 \\
\pm 4 .\end{array}$ & \begin{tabular}{|c|}
$86.473^{b}$ \\
\pm 3.382 \\
\end{tabular} & $\begin{array}{c}\text { 53.000 }^{\mathrm{ab}} \\
\pm \text { 3.099 }^{2}\end{array}$ & & $\begin{array}{l}17.295^{b} \\
\pm 0.676\end{array}$ \\
\hline & Jamu T & $\begin{array}{r}192 \\
\pm 5\end{array}$ & $\begin{array}{c}89.383^{a b} \\
\pm 3.262\end{array}$ & $\begin{array}{r}49.3 \\
\pm 3\end{array}$ & $\begin{array}{r}124 \\
\pm 2\end{array}$ & $\begin{array}{c}17.877^{\text {ab }} \\
\pm 0.652\end{array}$ \\
\hline
\end{tabular}

Values are expressed as mean $\pm S D$. Significance at $p<0.05$.

BWG\%: Body weight gain \%.

Values which don't share the same letter in each column are significantly different.

TG: Triglycerides. HDL-c: High density lipoprotein cholesterol

LDL-c: Low density lipoprotein cholesterol

VLDL-c: Very low density lipoprotein cholesterol 
Table (3): Effect of some drugs and herbs on serum glucose and liver enzymes of obese rats.

\begin{tabular}{|c|c|c|c|c|}
\hline & \multirow{2}{*}{$\begin{array}{l}\text { Glucose } \\
\text { mg/dl }\end{array}$} & \multicolumn{2}{|c|}{ U/L } \\
\hline & & & AST & ALT \\
\hline \multicolumn{2}{|c|}{$\begin{array}{l}\text { Normal rats (-ve) fed on basal } \\
\text { diet. }\end{array}$} & $\begin{array}{l}70.467^{\mathrm{e}} \\
\pm 2.286\end{array}$ & $\begin{array}{l}15.667^{\mathrm{c}} \\
\pm 1.211\end{array}$ & $\begin{array}{l}6.167^{b} \\
\pm 0.753 \\
\end{array}$ \\
\hline \multicolumn{2}{|c|}{$\begin{array}{l}\text { Obese rats }(+v e) \text { fed on diet } \\
\text { containing } 20 \% \text { Protein and } \\
20 \% \text { Fat. }\end{array}$} & $\begin{array}{l}91.400^{\mathrm{a}} \\
\pm 2.228\end{array}$ & $\begin{array}{l}20.333^{\mathrm{a}} \\
\pm 2.251\end{array}$ & $\begin{array}{r}7.667^{\mathrm{a}} \\
\pm 0.517\end{array}$ \\
\hline \multirow{4}{*}{ 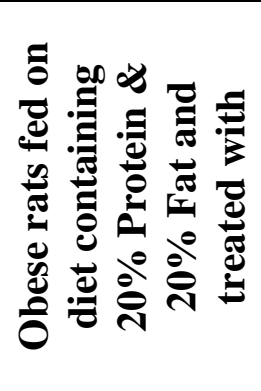 } & Orlistat & $\begin{array}{l}72.950^{\mathrm{de}} \\
\pm 1.898\end{array}$ & $\begin{array}{c}17.500^{\mathbf{b c}} \\
\pm 1.761\end{array}$ & $\begin{array}{r}6.000^{b} \\
\pm 1.095\end{array}$ \\
\hline & Chitosan & $\begin{array}{l}75.038^{d} \\
\pm 2.266\end{array}$ & $\begin{array}{l}18.500^{b} \\
\pm 1.643\end{array}$ & $\begin{array}{l}6.667^{\mathbf{a b}} \\
\pm 1.033\end{array}$ \\
\hline & Neopuntia & $\begin{array}{l}86.300^{b} \\
\pm 1.510\end{array}$ & $\begin{array}{l}17.167^{\mathbf{b c}} \\
\pm 0.753\end{array}$ & $\begin{array}{l}6.500^{\mathbf{a b}} \\
\pm 1.049\end{array}$ \\
\hline & Jamu Tea & $\begin{array}{l}83.220^{c} \\
\pm 3.026\end{array}$ & $\begin{array}{l}16.333^{c} \\
\pm 0.817\end{array}$ & $\begin{array}{r}6.167^{b} \\
\pm 1.169\end{array}$ \\
\hline
\end{tabular}

Values are expressed as mean $\pm S D$.

Significance at $p<0.05$.

Values which don't share the same letter in each column are significantly different. 
Table (4): Effect of some drugs and herbs on kidney functions of obese rats.

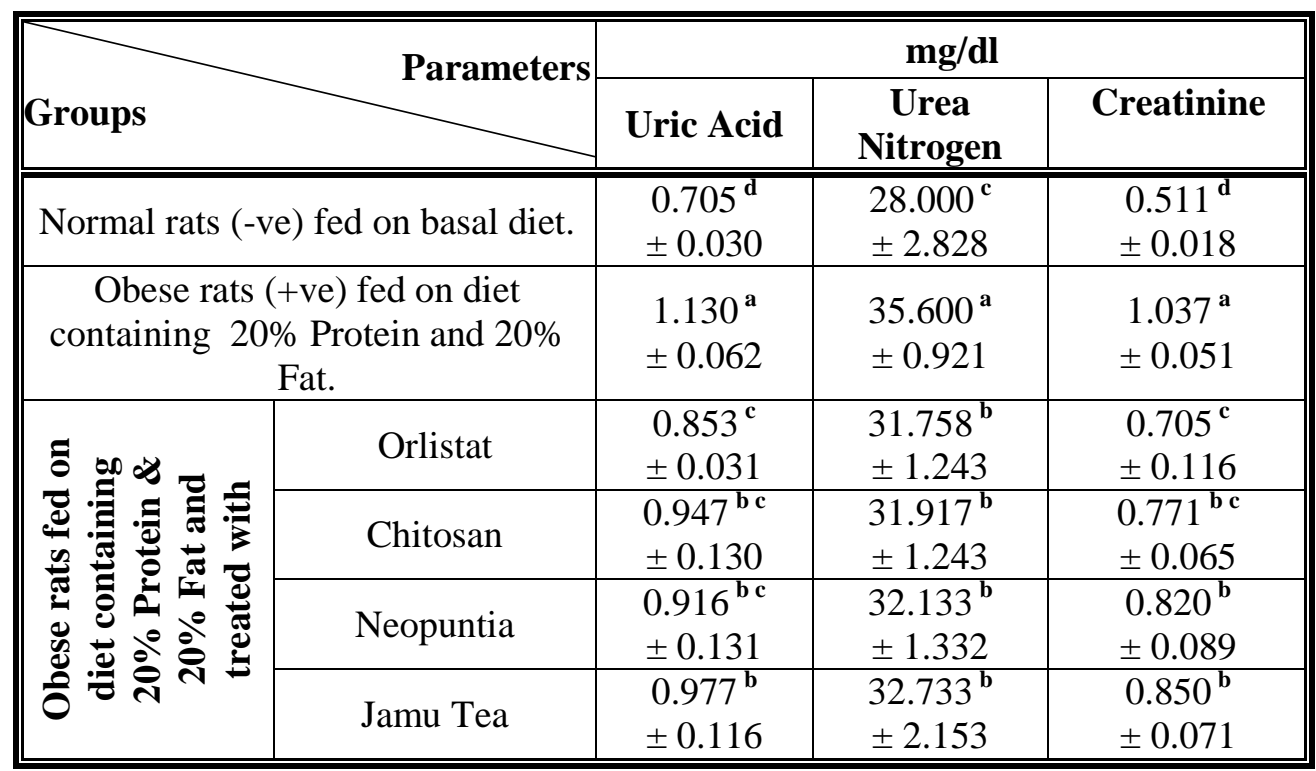

Values are expressed as mean $\pm S D$. Significance at $p<0.05$.

Values which don't share the same letter in each column are significantly different. 


\section{تأثير بعض الادوية والاعشاب علي فئران التجارب المصابة بالسهنة فاروق محمد التلاوىه ه - عطيات محمد البهى ه - عبد الرحمن محمد عطيةه - أثرف عبد

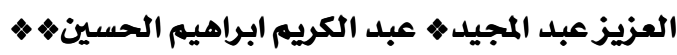 • قسم التغذية وعلوم الأطعمة - كلية الاقتصاد المنزلي - جامعة حلوان ها هـم الاقتصاد المنزلي - كلية التربية النوعية - جامعة عين شمس} a_2030@ hotmail.com القاهرة - جمهورية مصر العربية المستخلص

تهدف هذه الدراسة الي معرفة تأثير بعض الادوية (الاورليستات و الشيتوزان) و الاعشاب

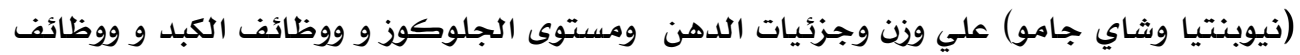

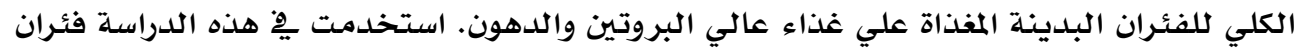



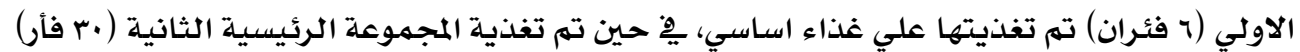

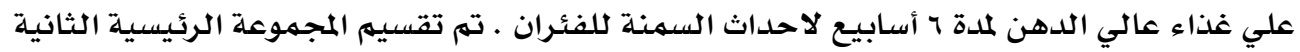

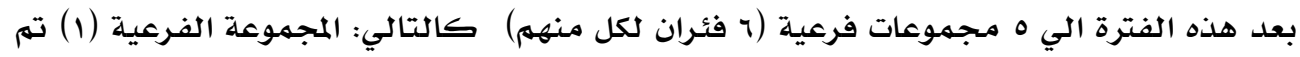

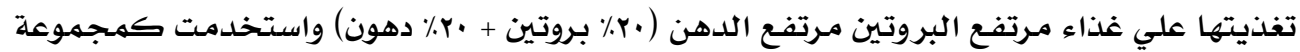

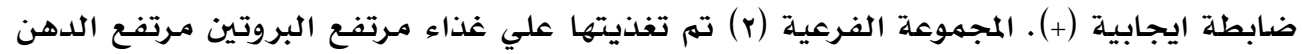



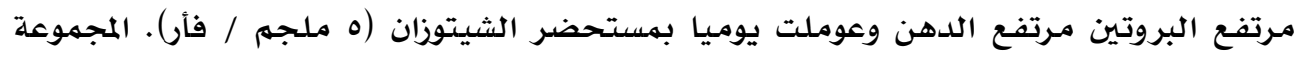

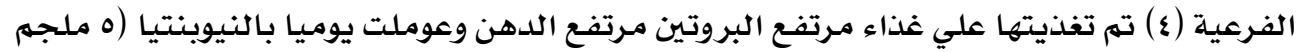

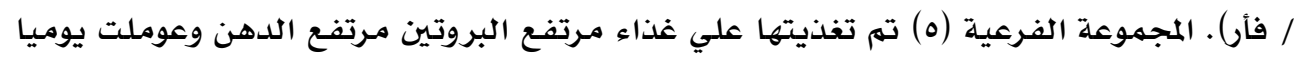
بشاى جامو (ه مللي / فأر ).

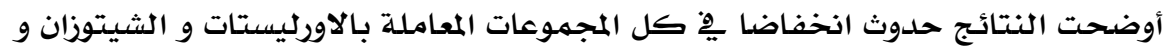
النيوبنتيا وشاى جامو، كذلك حدوث تحسنا ِِّ صورة الدهن (كولسترول - جلسريدات ثلاثية -

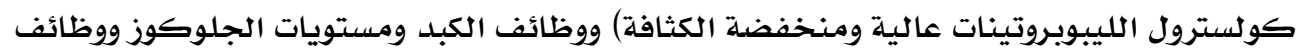

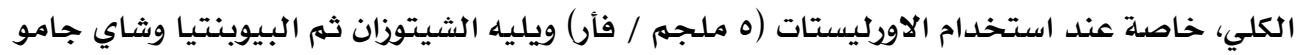
علي التوالي.

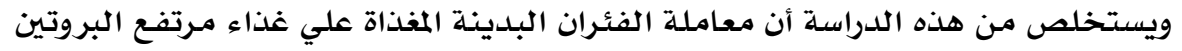

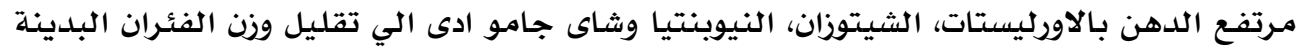
وحسنت وظائف الجسهم. الكلمات المفتاحية: فئران، أورليستات، شيتوزان، نيوبنتيا، شاي جامو، صورة الدهن، وظائف الكبد، 